\title{
PENAMBAHAN GEL LIDAH BUAYA SEBAGAI ANTIBAKTERI PADA SABUN MANDI CAIR BERBAHAN DASAR MINYAK KELAPA
}

\author{
Additional Oo Aloe Vera Gel as Antibactery in Liquid Bath Soap Based Coconut Oil \\ Sukma Budi Ariyani dan Hidayati \\ Baristand Industri Pontianak Jln. Budi Utomo No. 41 Pontianak 78243 \\ Email : sukma_ariyani@yahoo.co.id
}

\begin{abstract}
ABSTRAK. Sabun cair dibuat melalui reaksi saponifikasi dari minyak dan lemak yang direaksikan dengan $\mathrm{KOH}$. Gel lidah buaya digunakan sebagai antibakteri dan memiliki kandungan zat yang baik untuk kulit. Penelitian ini bertujuan memperoleh karakteristik gel lidah buaya, memperoleh produk sabun mandi cair dengan penambahan gel lidah buaya dan mengetahui aktivitas antibakteri Escherichia coli pada sabun mandi cair yang diperoleh. Metode penelitian yang dilakukan meliputi pembuatan sediaan gel lidah buaya, pengujian gel lidah buaya, pembuatan sabun mandi cair berbahan dasar minyak kelapa, pengujian sabun mandi cair sesuai SNI dan uji daya hambat bakteri Escherichia coli. Variabel berubah yang digunakan adalah konsentrasi gel lidah buaya yang ditambahkan pada pembuatan sabun mandi cair (5, 10 dan 15\%). Hasil yang diperoleh adalah gel lidah buaya dapat dijadikan sebagai bahan pembuatan produk kosmetik. Gel lidah buaya ini mengandung zat saponin, antrakuinon, lignin dan 18 jenis asam amino. Produk sabun mandi cair yang diperoleh, untuk parameter keadaan, $\mathrm{pH}$, bobot jenis alkali bebas dan angka lempeng total, hasilnya memenuhi SNI sabun mandi cair (SNI 06-4085-1996) dan memiliki daya hambat terhadap bakteri Escherichia coli dengan diameter zona hambat rata-rata sebesar 1,85 cm dengan metode uji cakram dish.
\end{abstract}

Kata kunci : Escherichia coli, gel lidah buaya, minyak kelapa, sabun mandi cair

ABSTRACT. Liquid soap is made by saponification reaction of oil and fat reacted with $\mathrm{KOH}$. Aloe vera gel is used as an antibacterial and has a good substance for the skin. The objective of this study was to obtain the characteristics of aloe vera gel, to obtain liquid bath soap product with the addition of aloe vera gel and to know the antibacterial activity of Echerichia coli on the obtained liquid bath soap. Methods of research include preparation of aloe vera gel, aloe vera gel testing, making liquid bath soap made from coconut oil, liquid bath soap test in accordance with SNI and inhibitory test of Escherichia coli bacteria. The altered variables used were aloe vera gel concentrations added to the manufacture of liquid bath soap $(5,10$ and $15 \%)$. The results obtained are aloe vera gel can be used as material for cosmetic products. Aloe vera gel contains saponins, anthraquinone, lignin and 18 types of amino acids. Liquid bath soap product obtained, for state parameters, $\mathrm{pH}$, total weight free alkali and total plate number, the result meets the SNI 06-40851996 and has a resistance to the bacteria Escherichia coli with an inhibitory zone diameter of $1.85 \mathrm{~cm}$ with the test method dish disc.

Keywords : aloe vera gel, coconut oil, Esherichia coli, liquid bath soap

\section{PENDAHULUAN}

Sabun merupakan pembersih yang dibuat dengan reaksi kimia antara kalium atau natrium dengan asam lemak dari minyak nabati atau lemak hewani. Sabun cair lebih diminati oleh masyarakat dibandingkan dengan sabun padat, karena penggunaannya yang lebih praktis, lebih hemat, tidak terkontaminasi bakteri, mudah dibawa dan mudah disimpan (Agusta, 2016).

Sabun mandi cair adalah sediaan berbentuk cair yang digunakan untuk membersihkan kulit, dibuat dari bahan dasar sabun dengan penambahan surfaktan, penstabil busa, pengawet, pewarna dan pewangi yang diijinkan dan digunakan untuk mandi tanpa menimbulkan iritasi pada kulit. Sabun cair dibuat melalui reaksi saponifikasi dari minyak dan lemak dengan $\mathrm{KOH}$ (Irmayanti, et al., 2014).

Seiring perkembangan ilmu pengetahuan dan teknologi dibidang kimia dan farmasi, perkembangan kosmetik mulai bergeser ke arah natural product karena adanya trend back to nature (Duraisam, et al., 2011). Salah satu herbal yang dapat ditambahkan dalam sediaan kosmetik sabun mandi cair adalah gel lidah buaya.

Menurut Woodroof (1979), minyak kelapa diperoleh sebagai hasil ekstraksi 
daging buah kelapa segar. Asam-asam lemak dominan yang menyusun minyak kelapa adalah laurat dan miristat, yang merupakan asam-asam lemak berbobot molekul rendah, sedangkan menurut Ketaren (1986), minyak kelapa memiliki sekitar $90 \%$ kandungan asam lemak jenuh. Shrivastava (1982) menyatakan bahwa minyak kelapa memiliki sifat mudah tersaponifikasi (tersabunkan). Hal tersebut menjadi dasar dijadikannya minyak kelapa sebagai bahan dasar sabun mandi cair.

Lidah buaya Pontianak jenis Barbadensis memiliki kandungan senyawa lignin yang lebih tinggi dibandingkan lidah buaya yang ditanam di daerah lain karena berada di bawah garis khatulistiwa dengan tekstur tanah gambut dan intensitas cahaya matahari yang tinggi.

Lidah buaya adalah salah satu tanaman yang berkhasiat untuk menjaga kesehatan kulit. Keistimewaan lidah buaya terletak pada gelnya yang mampu untuk meresap di dalam jaringan kulit, sehingga banyak menahan kehilangan cairan yang terlalu banyak dari dalam kulit (Hartanto dan Lubis, 2002). Gel lidah buaya juga memiliki kandungan zat antibakteri dan antijamur.

Penggunaan sabun mandi cair merupakan salah satu cara untuk melindungi kulit dari infeksi bakteri dan mencegah penyakit infeksi kulit. Infeksi merupakan penyakit yang sering terjadi karena adanya mikroorganisme yang masuk ke dalam tubuh sehingga menyebabkan gangguan fisiologi normal tubuh. Escherichia coli merupakan bakteri penyebab infeksi tersering dan umum. Penggunaan antibakteri dari bahan sintetik dapat mencegah terjadinya infeksi, namun tidak sedikit yang memberikan efek samping seperti iritasi. Hal ini mendorong beralihnya penggunaan sediaan yang berasal dari alam (Rosdiyawati, 2014). Salah satu bahan alam yang dapat dimanfaatkan sebagai antibakteri adalah gel lidah buaya Pontianak.

Sediaan yang lazim dijumpai seperti pada sabun, gel, salep atau lotion dapat langsung menuju bagian yang terinfeksi. Sediaan juga diharapkan memiliki daya antibakteri yang cukup untuk menghambat pertumbuhan bakteri Escherichia coli.

\section{METODOLOGI}

\section{Alat dan Bahan}

Bahan yang digunakan adalah lidah buaya, sodium benzoate, $\mathrm{KOH}$, minyak kelapa dan asam sitrat.

Alat yang digunakan diantaranya pisau, beaker glass, gelas ukur, botol sampel, kain saring, heater magnetic stirrer, pengaduk, digital refraktometer dan rotary vacuum evaporator.

\section{Pembuatan Sediaan Gel Lidah Buaya}

Lidah buaya Barbadensis dicuci terlebih dahulu dan dihilangkan durinya, kemudian dipotong dan dikupas. Setelah itu dihaluskan dengan blender, disaring hingga diperoleh filtrat berupa jus lidah buaya. Dilakukan pemekatan jus lidah buaya dengan alat rotary vacuum evaporator seperti pada Gambar 1., kondisi operasi:

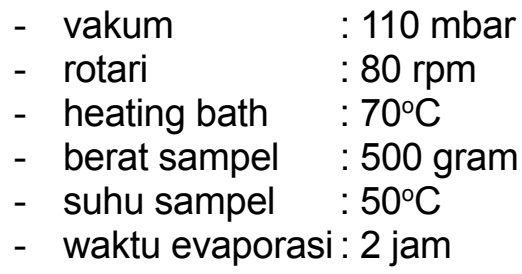

Sehingga diperoleh gel dengan brix 4-5,5, diukur dengan digital refraktometer. Gel lidah buaya yang diperoleh ditambah sodium benzoat dengan konsentrasi $0,1 \%$ untuk mempertahankan kestabilan gel yang diperoleh.

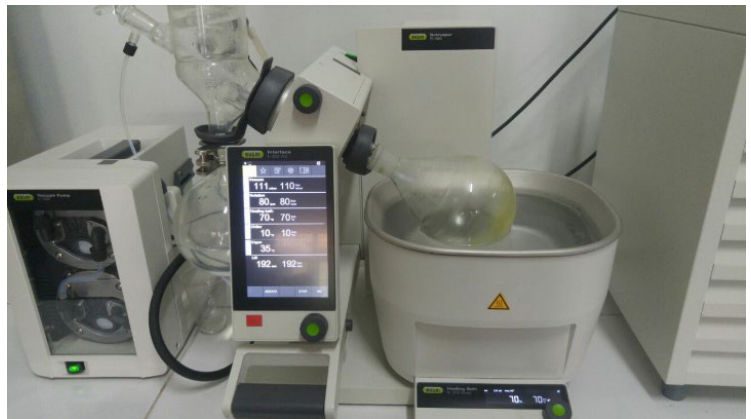

Gambar 1. Rotary Vacuum Evaporator

\section{Pengujian Gel Lidah Buaya}

Gel lidah buaya yang diperoleh diuji $\mathrm{pH}$, TDS, kandungan saponin, antrakuinon, vitamin $A$, vitamin $C$ dan asam amino. 


\section{Pembuatan Sabun Mandi Cair}

Pembuatan sabun mandi cair diawali dengan pembuatan soap base. Minyak kelapa, akuades dan $\mathrm{KOH}$ ditimbang di tempat terpisah. Minyak kelapa ditimbang sebanyak 300 gram, akuades ditimbang sebanyak 228 gram dan $\mathrm{KOH}$ ditimbang sebanyak 76 gram. Minyak kelapa dipanaskan hingga mencapai suhu $70^{\circ} \mathrm{C}$ dan dipertahankan pada suhu tersebut. $\mathrm{KOH}$ dimasukkan ke dalam akuades, diaduk hingga homogen. Larutan $\mathrm{KOH}$ yang telah siap dimasukkan ke dalam minyak yang telah dipanaskan. Campuran tersebut diaduk menggunakan mixer selama 20 menit hingga campuran menjadi tebal dan padat. Langkah selanjutnya adalah memanaskan soap base. Campuran (soap base) dimasukkan ke dalam waterbath yang diisi dengan air yang telah mendidih. Soap base dipanaskan selama 3 jam dan diaduk setiap 30 menit sekali. Awalnya soap base berwarna putih susu dipanaskan hingga menjadi jernih dan transparan. Hasil soap base dapat disimpan di kulkas jika tidak langsung digunakan. Langkah berikutnya adalah pembuatan sabun cair yakni meliputi soap base ditimbang sebanyak 200 gram dan akuades juga ditimbang sebanyak 200 gram. Akuades dipanaskan hingga mendidih kemudian larutkan soap base ke dalam akuadesmendidih. Campurantersebutdiaduk terus hingga larut dengan pemanasan stabil $50^{\circ} \mathrm{C}$ dengan heater magnetik stirrer. Setelah kira-kira hampir larut, tambahkan asam sitrat sebanyak 1,84 gram yang telah dilarutkan ke dalam akuades sebanyak 7,36 gram yang telah mendidih. Campuran diaduk selama 1 jam. Setengah jam sebelum pengadukan selesai, gel lidah buaya ditambahkan ke dalam campuran dengan konsentrasi 5, 10, $15 \%$ dari berat soap base yang digunakan. $\mathrm{Hal}$ ini dilakukan agar bahan sebelumnya tercampur homogen terlebih dahulu. Setelah selesai pengadukan, dilakukan penyaringan hingga diperoleh sabun cair yang diinginkan.

\section{Pengujian Sabun Mandi Cair}

Sabun mandi cair yang diperoleh diuji sesuai parameter yang terdapat dalam SNI 06-4085-1996 yakni meliputi parameter keadaan (bentuk, bau, warna), pH, alkali bebas, bahan aktif, bobot jenis dan Angka Lempeng Total (ALT).
Ujt Daya Hambat Escherichia coli pada Sabun Mandi Cair dengan Metode Cakram Dish

Cakram dicelupkan ke dalam sampel (sabun cair) sampai merata di seluruh permukaan cakram. Media nutrient agar yang telah disterilkan dituangkan ke dalam petridish. Media nutrient agar yang telah dingin dan memadat selanjutnya ditanami bakteri. Bakteri sebelumnya telah dibiakkan terlebih dahulu. Bakteri yang ditanam, diratakan hingga seluruh permukan nutrient agar dengan menggunakan spreader. Kemudian cakram tersebut diletakkan dalam media nutrient agar yang telah ditanami bakteri, selanjutnya diinkubasi selama 24 jam. Aktifitas antibakteri ditunjukkan oleh luas diameter zona bening yang terbentuk.

\section{HASIL DAN PEMBAHASAN}

Hasil uji gel lidah buaya dapat dilihat pada Tabel 1 dan hasil uji sabun mandi cair sesuai parameter dalam SNI dapat dilihat pada Tabel 2. Sedangkan hasil gel lidah buaya yang diperoleh dapat dilihat pada Gambar 2.

Tabel 1. Hasil Uji Gel Lidah Buaya

\begin{tabular}{clc}
\hline No. & Parameter & $\begin{array}{c}\text { Gel Lidah } \\
\text { Buaya }\end{array}$ \\
\hline 1. & pH & 4,33 \\
2. & TDS $(\mathrm{mg} / \mathrm{L})$ & 46932 \\
3. & Saponin $(\mathrm{mg} / \mathrm{kg})$ & 977,91 \\
4. & Antrakuinon $(\mathrm{mg} /$ & 126,81 \\
5. & Lignin (\%) & 11,58 \\
6. & Vitamin C (\%) & 0,00538 \\
7. & Vitamin A & 30,77 \\
8. & Ascgm Amino & \\
& L-Histidin (ppm) & 40,86 \\
& L-Threonin (ppm) & 71,88 \\
& L-Prolin (ppm) & 41,66 \\
& L-Tirosin (ppm) & 66,93 \\
& L-Leusin (ppm) & 67,81 \\
& L-Asam Aspartat & 119,93 \\
(ppm) & 46,95 \\
& L-Lisin HCl (ppm) & \\
&
\end{tabular}


Glisin (ppm)

120,72

L-Arginin (ppm)

45,99

L-Alanin (ppm)

101,7

L-Valin (ppm)

46,74

L-Isoleusin (ppm)

37,82

L-Fenilalanin

(ppm)

35,22

L-Asam glutamat

(ppm)

118,35

L-Serin (ppm)

249,3

L-Metionin (ppm)

12,81

L-Sistin (ppm)

48,42

L-triptofan (ppm) 16,86

Tabel 2. Hasil Uji Sabun Mandi Cair Sesuai Parameter dalam SNI

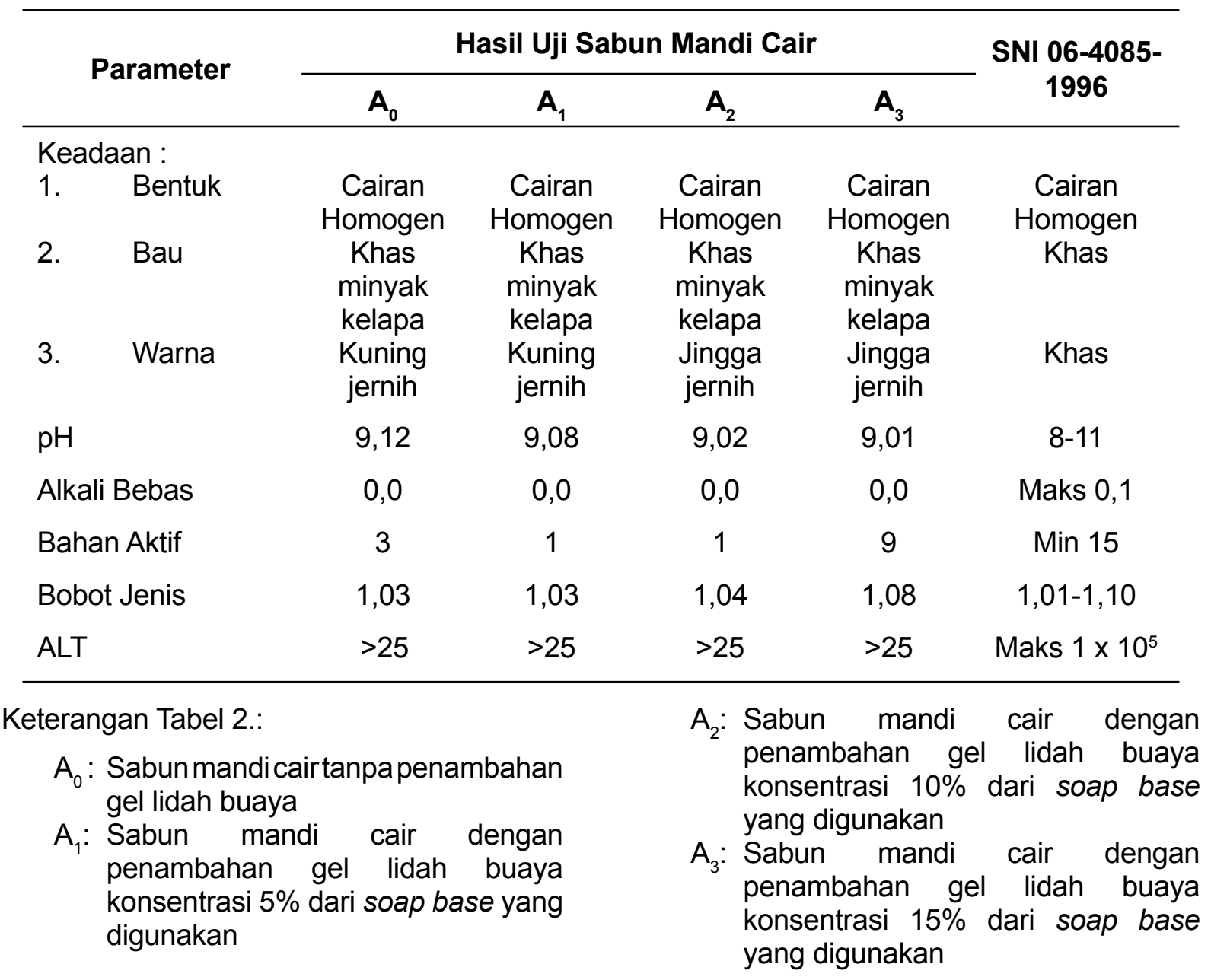




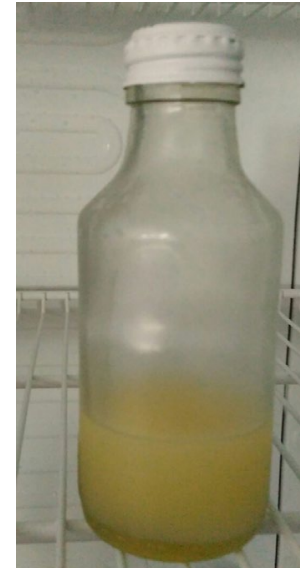

Gambar 2. Gel lidah buaya

\section{Hasil Uji Gel Lidah Buaya}

\section{a. $\mathrm{pH}$}

$\mathrm{pH}$ alami gel lidah buaya bersifat asam adalah antara 4-5 (Padmadisastra, et al., 2013). Sedangkan menurut standar Terry Laboratories, $\mathrm{pH}$ gel lidah buaya yakni 3,5 sampai 4,5. Pada Tabel 1., pH gel lidah buaya yang diperoleh adalah 4,33 (memenuhi standar Terry Laboratories).

\section{b. Saponin, Lignin dan Antrakuinon}

Lidah buaya (Aloe vera (L.) Webb.) memiliki banyak manfaat yakni sebagai sumber penghasil bahan baku untuk aneka produk industri makanan, farmasi, dan kosmetik. Lidah buaya memiliki kandungan saponin yang mempunyai kemampuan untuk membersihkan dan bersifat antiseptik. Pemanfaatan lidah buaya sebagai bahan pembuatan sabun, tidak hanya mampu membunuh bakteri, tetapi juga dapat melembutkan kulit. Hal ini disebabkan karena adanya lignin yang berguna untuk menjaga kelembaban kulit serta menahan air di dalam kulit, sehingga tidak terjadi penguapan yang berlebihan (Gusviputri, et al., 2013).

Dilihat pada Tabel 1., diperoleh kadar saponin, lignin dan antrakuinon dalam gel lidah buaya masing-masing sebesar 977,91 $\mathrm{mg} / \mathrm{kg}, 11,58 \%$ dan $126,81 \mathrm{mg} / \mathrm{kg}$. Saponin larut dalam air membentuk buih seperti buih sabun, hal ini disebabkan karena saponin mempunyai amphiphilik. Saponin untuk obat luar biasanya bersifat membersihkan. Saponin memiliki kemampuan sebagai pembersih dan antiseptik yang berfungsi membunuh atau mencegah pertumbuhan
mikroorganisme(Robinson, 1995)sedangkan senyawa antrakuinon mempunyai beberapa macam fungsi yaitu antiseptik, antibakteri, antikanker, dan pencahar (Rohyani, et al., 2015).

Saponin merupakan glikosida yang larut dalam air dan etanol, tetapi tidak larut dalam eter. Saponin bekerja sebagai antibakteri dengan mengganggu stabilitas membran sel bakteri sehingga menyebabkan sel bakterilisis, jadi mekanisme kerja saponin termasuk dalam kelompok antibakteri yang mengganggu permeabilitas membran sel bakteri, yang mengakibatkan kerusakan membran sel dan menyebabkan keluarnya berbagai komponen penting dari dalam sel bakteri yaitu protein, asam nukleat dan nukleotida (Darsana, et al., 2012).

Antrakuinon merupakan suatu antimikroba yang berspektrum luas. Lidah buaya mengandung beberapa glikosida antrakuinon (aloin, aloe-emodin dan barbaloin). Aloe-emodin bersifat bakterisidal terhadap Sreptococcus mutans. Salah satu mekanismenya adalah dengan menghambat transfer elektron pada rantai pernapasan mitokondria (Rahardja, et al., 2010).

\section{c. Asam Amino}

Dilihat pada Tabel 1., gel lidah buaya memiliki kandungan 18 jenis asam amino. L-serin adalah jenis asam amino dengan kandungan terbesar dalam gel lidah buaya yakni sebesar 249,3 ppm.

\section{Sabun Mandi Cair yang Diperoleh}

\section{a. Uji Organoleptis/ Keadaan}

Hasil uji organoleptik sabun mandi cair yang diperoleh memiliki warna jingga jernih, pengaruh dari warna minyak kelapa yang digunakan. Bentuk sabun mandi cair yang dihasilkan berupa cairan homogen. Dari segi bau, bau yang ditimbulkan yaitu bau khas seperti minyak kelapa.

b. $\mathrm{pH}$

$\mathrm{pH}$ sabun mandi cair yang diperoleh masih dalam batas standar sesuai SNI 064085-1996 yakni 8-11. Semakin banyak gel lidah buaya ditambahkan pada sabun mandi cair, akan sedikit menurunkan $\mathrm{pH}$ sabun yang diperoleh karena sifat gel lidah buaya 
yang asam. Penurunan yang terjadi tidak signifikan terlihat dari hasil $\mathrm{pH}$ yang diperoleh. $\mathrm{pH}$ sabun cair yang diperoleh berkisar pada pH 9 (bersifat basa). Hal tersebut karena pembuatan sabun cair menggunakan $\mathrm{KOH}$. $\mathrm{KOH}$ bersifat basa kuat.

\section{c. Alkali Bebas}

Alkali bebas menunjukan banyaknya logam Alkali yang tidak tersabunkan dalam VCO pada proses saponifikasi, sehingga masih dalam bentuk logam alkalinya (Predianto, et al., 2017). Pada penelitian ini, VCO diganti dengan minyak kelapa. Pengujian alkali bebas diperlukan untuk mengetahui seberapa banyak logam alkali yang tidak tersabunkan, karena nantinya akan berpengaruh pada kualitas sabun mandi cair itu sendiri. Hasil penelitian alkali bebas sabun mandi cair yang diperoleh menunjukkan kadar alkali bebas sebanyak 0 $\%$, dapat dilihat pada Tabel 2 .

\section{d. Bahan Aktif}

Bahan aktif yang diukur adalah jumlah senyawa dalam sabun yang tidak tersabunkan (Predianto, et al., 2017). Hasil penelitian sabun mandi cair menunjukan kadar bahan aktif dalam sabun cair yang tertinggi adalah sebesar $9 \%$. Hal ini menunjukkan bahwa untuk bahan aktif dalam sabun mandi cair yang diperoleh belum memenuhi SNI 06-4085-1996 yang ada yakni minimal $15 \%$. Untuk menaikkan bahan aktif agar memenuhi SNI 06-40851996, dalam pembuatan sabun cair, dapat ditambahkan minyak yang mengandung asam lemak oleat seperti minyak zaitun, rice bran atau canola. Asam lemak oleat ini berfungsi untuk menambah kelembaban kulit. Penambahan konsentrasi gel lidah buaya saat proses pembuatan sabun cair dapat juga dilakukan untuk menambah total bahan aktif dalam sabun mandi cair.

\section{e. Bobot Jenis}

Bobot jenis sabun mandi cair yang dihasilkan dari penelitian ini adalah 1,031,08, dapat dilihat pada Tabel 2. Hasil ini menunjukkan bahwa bobot jenis dari sabun mandi cair yang diproduksi masih memenuhi standar SNI 06-4085-1996, yakni berkisar antara 1,01-1,10. Pengujian bobot jenis penting untuk dilakukan karena dapat menentukan apakah suatu zat padat dapat bercampur atau tidak dengan zat lainnya, maka akan mempermudah dalam formulasi sabun.

\section{f. Angka Lempeng Total}

Hasil uji angka lempeng total pada sabun mandi cair yang dihasilkan dari penelitian ini menunjukkan sedikit pertumbuhan mikroorganisme dalam sabun yakni sebesar < $25 \mathrm{koloni} / \mathrm{gram}$. Hal ini menunjukkan bahwa sabun mandi cair yang diperoleh relatif higienis dari mikroorganisme yang dapat membahayakan konsumen. Hasil uji angka lempeng total pada sabun mandi cair dalam penelitian ini memiliki angka cemaran mikroba yang memenuhi standar SNI 06-4085-1996 yakni kurang dari $1 \times 10^{5}$ koloni/gram.

\section{Uji Daya Hambat Escherichia coli}

Bakteri E. coli merupakan salah satu jenis kelompok bakteri yang kehadirannya sangat dihindari pada suatu benda yang berhubungan dengan manusia. Sejak diketahui bahwa jasad renik tersebut dapat tersebar pada semua individu, maka analisis bakteriologi air minum ditujukan pada kehadiran mikroorganisme tersebut.

Pada kondisi tertentu bakteri Escherichia coli menyebabkan penyakit diare, infeksi saluran kemih, pneumonia dan meningitis pada bayi baru lahir serta infeksi luka dalam. Pemberian antibakteri merupakan salah satu pilihan dalam menangani penyakit infeksi. Namun penggunaan antibakteri yang tidak terkontrol dapat mendorong terjadinya perkembangan resistensiterhadap antibakteriyang diberikan. Adanya resistensi ini dapat menimbulkan banyak masalah dalam pengobatan penyakit infeksi, sehingga diperlukan usaha untuk mengembangkan obat tradisional berbahan herbal yang dapat membunuh bakteri untuk menghindari terjadinya resistensi tersebut. Salah satu tanaman yang secara empiris digunakan sebagai bahan obat yaitu Aloe barbadensis atau lebih dikenal sebagai lidah buaya (Rahardjo, et al., 2017).

Lidah buaya diketahui mengandung emodin antrakuinon yang sebelumnya telah terbukti memiliki aktivitas antimikroba. 
Antrakuinon bekerja dengan cara menghambat sintesis protein sehingga bakteri tersebut tidak dapat tumbuh dalam media yang terdapat ekstrak lidah buaya. Aloe vera pun terdapat saponin yang mengandung glikosida yang memiliki efek antiseptik (Puteri dan Tiana, 2017).

Hasil sabun mandi cair terbaik diuji daya hambatnya terhadap bakteri Escherichia coli dengan metode cakram dish. Hasil yang diperoleh, sabun mandi cair yang menggunakan gel lidah buaya memiliki daya hambat bakteri Escherichia coli dengan diameter zona hambat rata-rata sebesar $1,85 \mathrm{~cm}$, perhitungan dapat dilihat pada Tabel 3. Menurut Davis dan Stout (1971) bahwa sampel dengan diameter zona bening 10-20 mm diklasifikasikan respon hambatan mikrobanya termasuk ke dalam ketegori kuat. Hasil uji dengan metode cakram dish dapat dilihat pada Gambar 3.

Tabel 3. Hasil pengukuran dengan metode cakram dish

\begin{tabular}{ccc}
\hline No. & Perlakuan & $\begin{array}{c}\text { Diameter yang } \\
\text { terbentuk (cm) }\end{array}$ \\
\hline 1. & Cakram 1 & 1,9 \\
2. & Cakram 2 & 1,8 \\
& Rata-rata & 1,85 \\
\hline
\end{tabular}

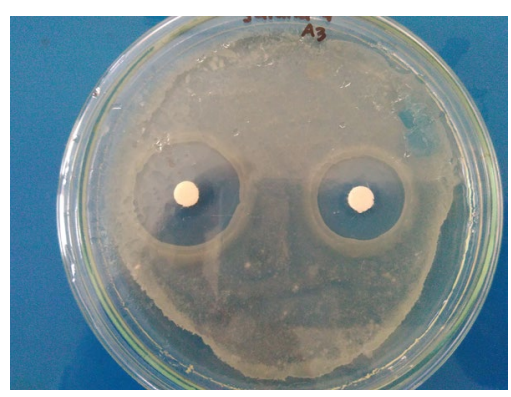

Gambar 3. Hasil Uji dengan Metode Cakram Dish

\section{SIMPULAN}

Gel lidah buaya hasil penelitian memiliki brix 4-5,5 dapat dijadikan sebagai bahan pembuatan produk sabun mandi cair. Gel lidah buaya ini mengandung zat saponin, antrakuinon dan lignin yang merupakan bahan aktif yang baik untuk kulit. Produk sabun mandi cair berbahan dasar minyak kelapa dan menggunakan gel lidah buaya, berdasarkan hasil uji yang diperoleh, parameter keadaan, $\mathrm{pH}$, bobot jenis, alkali bebas dan angka lempeng total, hasilnya memenuhi SNI sabun mandi cair (SNI 06-4085-1996). Sabun mandi cair yang diperoleh memiliki daya hambat terhadap bakteri Escherichia coli dengan diameter zona hambat rata-rata sebesar $1,85 \mathrm{~cm}$ dengan metode uji cakram dish.

\section{UCAPAN TERIMA KASIH}

Penulis mengucapkan terima kasih kepada Kepala Balai dan Kepala Seksi Teknologi Industri Baristand Industri Pontianak, rekan-rekan tim peneliti, dewan redaksi majalah dan semua pihak yang telah membantu sehingga penelitian ini dapat terlaksana dan tulisan ini dapat diterbitkan.

\section{DAFTAR PUSTAKA}

1. Agusta, W. Tri, 2016. Optimasi Formula Sabun Cair Antibakteri Ekstrak Etanol Daun Sirih Merah (Piper Crocatum Ruiz \& Pav) Dengan Variasi Konsentrasi VCO dan Kalium Hidroksida. Skripsi. Program Studi Farmasi. Fakultas Kedokteran. Universitas Tanjungpura Pontianak.

2. Ariyanti, Ni Kadek, Ida Bagus Gede Darmayasa dan Sang Ketut Sudirga. 2012. Daya Hambat Ekstrak Kulit Daun Lidah Buaya (Aloe barbadensis Miller) Terhadap Pertumbuhan Bakteri Staphylococcus aerus ATCC 25923 dan Escherichia coli ATCC 25922. Jurnal Biologi. Volume XVI. Nomor 1. Juni 2012.

3. Darsana, I. G. O., I. N. K. Besung dan H. Mahatmi. 2012. Potensi Daun Binahong (Anredera Cordifolia (Tenore) Steenis) dalam Menghambat Pertumbuhan Bakteri Escherichia Coli secara In Vitro, Indonesia Medicus Veterinus 2012; 1 ( 3), $337-51$.

4. Davis. Stout. 1971. Disc Plate Method of Microbiological Antibiotic Essay. Journal of Microbiology. 22(4).

5. Duraisamy, A., V. Krishnan dan K. P. Balakrishnan. 2011. Bioprospecting dan New Cosmetic Product Development: A brief review on the current status. International Journal of Natural Produch Research, p 26-37. 
6. Gusviputri, Arwinda, Njoo Meliana P.s, Aylianawati dan Nani Indraswati. 2013. Pembuatan Sabun dengan Lidah Buaya (Aloe vera) Sebagai Antiseptik Alami. Fakultas Teknik. Jurusan Teknik Kimia. Universitas Katolik Widya Mandala Surabaya.

7. Hartanto, E.S. dan E.H. Lubis. 2002. Pengolahan Minuman Sari Lidah Buaya (Aloevera linn.). Warta IHP/J. AgroBased Industry.

8. Irmayanti, P. Yunia, Ni Putu Ayu Dewi Wijayanti dan Cokorda Istri Sri Arisanti. 2014. Optimasi Formula Sediaan Sabun Mandi Cair dari Ekstrak Kulit Manggis (Garania Mangostana Linn.). Jurnal Kimia 8 (2), Juli 2014: 237-242.

9. Ketaren, S. 1986. Minyak dan Lemak Pangan. Jakarta : UI Press.

10. Padmadisastra, Y., Sidik, \& Sumi Ajizah. 2013. Formulasi sediaan cair gel lidah buaya (aloe vera linn.) sebagai minuman kesehatan. Simposium Nasional Kimia Bahan alam III, 1-13.

11. Predianto, Herwin, Lydia I. Momuat dan Meiske S. Sangi. 2017. Produksi Sabun Mandi Cair Berbahan Baku VCO yang Ditambahkan dengan Ekstrak Wortel (Daucus carrota). Chem. Prog. Volume 10. Nomor 1. Mei 2017.

12. Puteri, Teresya dan Tiana Milanda. 2017. Uji Daya Hambat Ekstrak Daun Lidah Buaya (Aloe vera L.) Terhadap Bakteri Escherichia coli dan Staphylococcus aureus : Review. Farmaka Suplemen Volume 14. Nomor 2.
13. Rahardja, F., Sugiarto Puradisastra, dan Arlene Angelin. 2010. Aktivitas Antimikroba Gel Lidah Buaya (Aloe Vera L.) pada Acne Vulgaris yang Terinfeksi Staphylococcus sp. Secara In Vitro, JKM 2010;10 (1). h. 30-6.

14. Rohyani, I. Suci, Evy Aryanti dan Suripto. 2015. Kandungan Fitokimia Beberapa Jenis Tumbuhan Lokal Yang Sering Dimanfaatkan Sebagai Bahan Baku Obat di Pulau Lombok. Prosiding Seminar Nasional Masyarakat Biodiv Indon. Volume 01. Nomor 02. April 2015. Hal 388-391.

15. Rosdiyawati, Risky. 2014. Uji Efektivitas Antibakteri Sediaan Sabun Mandi Cair Minyak Atsiri Kulit Buah Jeruk Pontianak (Citrus nobilis Lour. Var. Microcarpa) Terhadap Staphylococcus aerus dan Escherichia coli. Skripsi. Program Studi Farmasi. Fakultas Kedokteran. Universitas Tanjungpura Pontianak.

16. Shrivastava, S. B. 1982. Soap, Detergent, and Parfume Industry. New Delhi : Small Industry Research Institute

17. Sudarto, Y. 1997. Lidah Buaya. Yogyakarta : Kanisius.

18. Woodroof, J. G. 1979. Coconuts Production, Processing, Products. Second Edition. USA: The AVI Publishing Company, Inc. 